\title{
HUBUNGAN PEKERJAAN DAN JADWAL KERJA DENGAN INDEKS MASSA TUBUH BALITA DI WILAYAH KERJA PUSKESMAS YOSODADI KOTA METRO
}

\author{
Rilyani $^{1}$, Lidya Ariyanti2*, Calvyn Reza Trisnantyas ${ }^{3}$ \\ ${ }^{1}$ Dosen Program Studi Ilmu Keperawatan Universitas Malahayati \\ E-mail : simahayarily@gmail.com \\ ${ }^{2}$ Dosen Program Studi Ilmu Keperawatan Universitas Malahayati \\ E-mail : lidya.arianti@yahoo.co.id \\ ${ }^{3}$ Mahasiswi PSIK Universitas Malahayatl Bandar Lampung \\ E-mail : calvinreza282@gmail.com
}

Disubmit: 01 Desember 2021 Diterima: 31 Desember 2021 Diterbitkan: 01 Januari 2022 DOI: https://doi.org/10.33024/mnj.v1i1.5571

\section{ABSTRACT: EMPLOYMENT RELATIONSHIP AND WORKING SCHEDULE WITH BODY MASS INDEX IN YOSODADI PUSKESMAS WORKING AREA METRO CITY}

Introduction: The coverage of children under five in Lampung Province in 2019 was $79 \%$, where this figure was above the target (76.18\%). This figure illustrates that participation from the community to come to posyandu is still quite good in Lampung Province, while for Metro City the percentage of data is weighed at 78.8\%. Data obtained through the Metro City Health Office in 2020 at the Yosodadi Health Center obtained as many as 656 toddlers aged 1-5 years who were weighing

Objective: To find out the relationship between work and work schedule with the body mass index of toddlers aged 1-5 years.

Methods: This type of research is quantitative. The design in this study uses an analytical survey design with a cross sectional approach. The population is mothers and children aged 3-5 years, which is then calculated using the Slovin formula to obtain 197 children. Sampling technique purposive sampling Analysis of univariate and bivariate data using the chi square test.

Results: working mothers as many as 107 respondents (54.3\%)., standard work schedule is 8 hours per day as many as 109 respondents (55.3\%), BMl is not ideal, namely < 18.5 and $>22.9$ as many as 103 respondents ( $52.3 \%$. The results of statistical tests using the chi square test obtained $p$-value $=0.000(<a 0.05), p$ value $=0.085(>a 0.05)$.

Conclusion: The results of statistical tests using the chi square test obtained $p$ value $=0.000(<a 0.05)$ which means the relationship between mother's work and body mass index of toddlers aged 3-5. The $p$-value $=0.085(>a 0.05)$ which means that there is no relationship between the mother's work schedule and the body mass index of children aged 3-5 years. It is recommended that parents who have toddlers with underweight and obese nutritional status should pay more attention to parenting patterns

Keywords $\quad$ : Mother's Work Work Schedule, Toddler Body Mass Index

INTISARI: HUBUNGAN PEKERJAAN DAN JADWAL KERJA DENGAN INDEKS MASSA TUBUH BALITA DI WILAYAH KERJA PUSKESMAS YOSODADI KOTA METRO 
Pendahuluan: Cakupan balita ditimbang di Provinsi lampung tahun 2019 sebesar $79 \%$, dimana angka ini diatas target $(76,18 \%)$. Angka ini menggambarkan bahwa partisipasi dari masyarakat untuk datang ke posyandu masih cukup baik di Provinsi Lampung, sedangkan untuk Kota Metro persentase data ditimbang sebesar 78,8\%. Data yang diperoleh melalui Dinkes Kota Metro tahun 2020 di Puskesmas Yosodadi didapat sebanyak 656 balita usia 1-5 tahun yang melakukan penimbangan berat badan

Tujuan: Diketahui hubungan pekerjaan dan jadwal kerja dengan indeks massa tubuh balita usia 1-5 tahun.

Metode: Jenis penelitian kuantitatif, Rancangan dalam penelitian ini menggunakan desain Survei Analitik dengan pendekatan cross sectional. Populasi adalah ibu dan anak usia 3-5 tahun, yang kemudian dilakukan perhitungan sampel dengan rumus slovin didapat sebanyak 197 anak. Teknik sampling purposive sampling Analisa data univariat dan bivariat menggunakan uji chi square.

Hasil : ibu bekerja sebanyak 107 responden (54,3\%)., jadwal kerja standar yaitu 8 jam per hari sebanyak 109 responden (55,3\%), IMT tidak ideal yaitu < 18,5 dan $>22,9$ sebanyak 103 responden (52,3\%). Hasil uji statistik menggunakan uji chi square didapat nilai $p$-value $=0.000(<\mathrm{a} 0.05)$, nilai $p$-value $=0.085(>a 0.05)$.

Kesimpulan : Hasil uji statistik menggunakan uji chi square didapat nilai $p$-value $=0.000(<\mathrm{a} 0.05)$ yang artinya ada hubungan pekerjaan ibu dengan indeks massa tubuh balita usia 3-5. Nilai $p$-value $=0.085(>a 0.05)$ yang artinya tidak ada hubungan jadwal kerja ibu dengan indeks massa tubuh balita usia 3-5 tahun. Disarankan kepada orang tua yang memiliki balita dengan status gizi kurus dan gemuk, harus lebih memperhatikan lagi mengenai pola asuh anak

Kata Kunci : Pekerjaan Ibu Jadwal Kerja, Indeks Masa Tubuh Balita

\section{PENDAHULUAN}

Usia balita merupakan usia
dimana pertumbuhan dan perkembangan terjadi sangat pesat. Dihitung sejak hari pertama kehamilan, kelahiran bayi sampai usia 2 tahun atau yang dikenal dengan periode 1000 hari pertama kehidupan manusia merupakan "periode emas" atau "periode kritis" yang menentukan kualitas kehidupan (Wirjatmadi, 2012). Asupan gizi yang cukup baik dalam kuantitas dan kualitas sangat diperlukan pada masa ini. Apabila kebutuhan zat gizi ini tidak terpenuhi maka pertumbuhan dan perkembangan anak akan terhambat, yang akhirnya akan menyebabkan mereka akan menjadi generasi yang hilang (lost generation) (Wirjatmadi, 2012).

Indeks Massa Tubuh (IMT) merupakan suatu indikator yang diperlukan dalam menentukan status berat badan, apakah anak tersebut tergolong sangat kurus, kurus, normal, gemuk dan sangat gemuk/obesitas (Azwar, 2010). Indeks Massa Tubuh (IMT) merupakan nilai yang diperoleh dari perhitungan antara berat badan dan tinggi badan (Supariasa, 2016). Perhitungan IMT anak dan remaja berbeda dengan orang dewasa (Raihanata dan Wiriawan, 2016).

Pada orang dewasa, IMT relatif lebih konstan jadi pengukuran lebih mudah dilakukan, sedangkan pada anak-anak lebih rumit karena perubahan IMT berkaitan dengan kematangan usia. Pada pengukuran IMT anak, untuk mengetahui apakah IMT anak tersebut terlalu tinggi atau terlalu rendah perlu dipertimbangkan usia dan jenis kelamin karena pertumbuhan pada 
anak laki-laki dan perempuan berbeda (Situmorang, 2015).

Seorang anak dengan status berat badan normal IMT nya berada pada grafik tumbuh kembang sesuai dengan jenis kelamin berada di antara -2 SD sampai dengan 1 SD. Jika IMT berada di antara 1 SD sampai dengan 2 SD dan di atas 2 SD maka anak tersebut tergolong gemuk dan obesitas. Sedangkan, jika IMT anak berada di bawah -2 SD dan di bawah -3 SD pada grafik tumbuh kembang maka anak tersebut dikategorikan kurus dan sangat kurus (Rito et al., 2012). Kegemukan khususnya obesitas dan kekurusan pada anak mulai menjadi permasalahan di seluruh dunia yang membutuhkan perhatian khusus karena dapat menjadi ancaman bagi kesehatan anak tersebut (Supariasa, 2016).

Pengukuran status gizi didasarkan atas Standar World Health Organization (WHO, 2005) yang telah ditetapkan pada Keputusan Menteri Kesehatan Nomor 1995/Menkes/SK/XII/2010 tentang Standar Antropometri Penilaian Status Gizi Anak. Menurut standar tersebut, status gizi balita dapat diukur berdasarkan tiga indeks, yaitu berat badan menurut umur $(B B / U)$, tinggi badan menurut umur (TB/U), dan berat badan menurut tinggi badan (BB/TB). Gizi kurang dan gizi buruk merupakan status gizi yang didasarkan pada indeks berat badan menurut umur (BB/U). Riset Kesehatan Dasar (Riskesdas) tahun 2018 yang diselenggarakan oleh Kementerian Kesehatan menyatakan bahwa persentase gizi buruk pada balita usia 0-23 bulan di Indonesia adalah 3,8\%, sedangkan persentase gizi kurang adalah 11,4\% (Kemenkes RI, 2020).

Hal tersebut tidak berbeda jauh dengan hasil Pemantauan Status Gizi (PSG) yang diselenggarakan oleh Kementerian Kesehatan tahun 2017, yaitu persentase gizi buruk pada balita usia 0-23 bulan sebesar 3,5\% dan persentase gizi kurang sebesar $11,3 \%$. Provinsi dengan persentase tertinggi gizi buruk dan gizi kurang pada balita usia 0-23 bulan tahun 2018 adalah Nusa Tenggara Timur, sedangkan provinsi dengan persentase terendah adalah Provinsi Jawa Barat. Sedangkan Provinsi Lmapung berada pada urutan ke 8 persentase status gizi buruk dan gizi kurang sebesar 10,20\% (Kemenkes RI, 2020).

Berdasarkan Riskesdas tahun 2018 balita dengan status gizi yang kurang $12,81 \%$ dan balita dengan gizi buruk sebesar 3,13\%. Melihat data tabel BB/U balita diatas, Kab/Kota dengan status gizi buruk dengan prevalensi tertinggi di kabupaten Tulang Bawang Barat sebesar 5,82\% dan terendah Di kota Metro sebesar $1,70 \%$ (Profil Dinkes Provinsi Lampung, 2019).

Cakupan balita ditimbang di Provinsi lampung tahun 2019 sebesar $79 \%$, dimana angka ini diatas target (76,18\%). Angka ini menggambarkan bahwa partisipasi dari masyarakat untuk datang ke posyandu masih cukup baik di Provinsi Lampung, sedangkan untuk Kota Metro persentase data ditimbang sebesar 78,8\% (Dinkes Provinsi Lampung, 2019).

Masalah kesehatan masyarakat dianggap serius bila prevalensi BB/U berat-kurang antara 20,0 - 29,0 persen, dan dianggap prevalensi sangat tinggi bila $=30$ persen(WHO 2010). Pada tahun 2018, secara nasional prevalensi BB/U (Underweight) berat-kurang pada anak balita di Provinsi Lampung mengalami penurunan dari $18,8 \%$ menjadi 15,94 persen, yang artinya masalah berat-kurang di Provinsi Lampung belum merupakan masalah kesehatan akan tetapi tetap perlu diwaspadai (Dinkes Provinsi Lampung, 2019). 
Faktor-faktor

yang

mempengaruhi status gizi antara lain: kurangnya informasi, kurangnya daya beli masyarakat, dan pekerjaan orang tua. Pekerjaan orang tua berkaitan dengan pendapatan keluarga, sehingga bisa dikatakan bahwa jenis pekerjaan juga bisa menentukan seseorang untuk memenuhi kebutuhan gizi keluarga. Ibu yang bekerja memiliki waktu yang lebih sedikit untuk mengasuh anaknya dibandingkan ibu yang tidak bekerja, sehingga akan berpengaruh pada kualitas perawatan anak sehingga mempengaruhi status gizi anak. Ibu yang bekerja dengan jam kerja pagi sampai sore maka ibu tidak mempunyai banyak waktu untuk memperhatikan makanan dan kebutuhan nutrisi anaknya (Agus, 2012).

Bekerja umumnya merupakan kegiatan yang menyita waktu. Bekerja bagi ibu-ibu akan mempunyai pengaruh terhadap kehidupan sehingga ibu tidak punya banyak waktu untuk mendapat informasi. Manusia memerlukan pekerjaan untuk dapat berkembang dan berubah. Seseorang bekerja bertujuan untuk mencapai suatu keadaan yang lebih dari keadaan yang sebelumnya. Seseorang yang bekerja dapat berbuat sesuatu yang bernilai, bermanfaat, dan memperoleh berbagai pengalaman (Nafi'ah, 2015).

Kesehatan mental ibu dan perilaku pengasuhan anak dapat mewakili saluran penting lainnya yang melaluinya pekerjaan tidak standar dapat memengaruhi BMI anak. Bukti menunjukkan bahwa pekerjaan tidak standar dapat membuat orang tua stres, yang dapat mempengaruhi tidur mereka dan meningkatkan depresi (Fenwick \& Tausig, 2001). Kelelahan, stres, dan depresi ibu mungkin berperan dalam mengadopsi perilaku ibu yang merusak kesehatan (misalnya, kurangnya latihan fisik atau kebiasaan makan yang tidak sehat) yang dicontohkan oleh anak-anak. Ibu yang lelah atau stres karena pekerjaan pada waktu-waktu yang tidak standar juga cenderung tidak merencanakan waktu makan dan menyiapkan makanan sehat, dan lebih cenderung mengandalkan makanan siap saji atau siap saji (Devine, Jastran, Jabs, Wethington, Farell, \& Bisogni, 2006; Jabs, Devine, Bisogni, Farrell, Jastran, \& Wethington, 2007).

Data status gizi kurang di Puskesmas Yosodadi di tahun 2019 sebanyak 57 kasus $(9,6 \%)$ dari 592 balita usia 1-5 tahun. Data yang diperoleh melalui Dinkes Kota Metro tahun 2020 di Puskesmas Yosodadi didapat sebanyak 656 balita usia 1-5 tahun yang melakukan penimbangan berat badan di Wilayah Kerja Puskesmas Yosodadi Kota Metro selanjutnya dilakukan dilakukan pencatatan responden dengan usia 3-5 tahun didapat jumlah sebanyak 387 responden $(58,9 \%)$ dan sebanyak 69 responden $(10,5 \%)$ memiliki masalah berat badan dengan status gizi kurang, dengan pengukuran berat badan berdasarkan usia BB/U dan tinggi badan berdasarkan usia $T B / U$ diantaranya berat badan kurang dan lebih (Data Dinkes Kota Metro, 2020).

Sedangkan dilihat dari pekerjaannya peneliti melakukan prasurvey secara acak dengan melakukan wawancara bebas terhadap 15 ibu yang mengantar anak ke Posyandu, didapat 10 ibu yang bekerja, dan diantaranya bekerja sebagai buruh, pegawai minimarket ataupun swalayan, pegawai konter dan waiters. Sedangkan 5 responden lainnya merupakan ibu rumah tangga yang tidak bekerja diluar rumah.

Berdasarkan uraian di atas, aktivitas fisik merupakan salah satu faktor terjadinya malnutrisi pada ibu 
hamil dimana kondisi tersebut akan berpengaruh berat badan lahir bayi. Selanjutnya peneliti hanya memilih responden yang berusia 3-5 tahun, hal ini disebabkan berdasarkan pertimbangan dari WHO dan Kemenkes RI yang menyatakan jika $\mathrm{BB} / \mathrm{U}, \mathrm{TB} / \mathrm{U}$ dapat dijadikan alat ukur untuk melihat status gizi anak, sedangkan anak ausia dibawah 3 tahun, belum mampu kooperatif, dan akan lebih sulit untuk menenangkan saat ditimbang, selain itu jika diukur tinggi badannya, anak usia di bawah 3 tahun belum mampu berdiri dengan tegak, sehingga berdampak pada hasil pengukuran.

\section{METODE PENELITIAN}

Jenis penelitian kuantitatif, dengan menggunankan rancangan penelitian yaitu rancangan praeksperimen (pra-experiment design). Rancangan eksperimen yang dilakukan dengan pratest-postest kelompok tunggal (one group pratest posttest). Populasi dalam penelitian ini adalah seluruh ojek baik ojek pangkalan ataupun ojek online yang berjumlah 178 orang. Teknik sampling pada penelitian ini adalah purposive sampling. Analisa data univariat dan bivariat menggunakan uji $t$-tes dependen.

\section{HASIL PENELITIAN DAN PEMBAHASAN Analisa Univariat}

Tabel 1

Distribusi Frekuensi Pekerjaan Ibu Di Wilayah Kerja Puskesmas Yosodadi Kota Metro Tahun 2021

\begin{tabular}{ccc}
\hline Pekerjaan & Frekuensi & Persentase (\%) \\
\hline Bekerja & 107 & 54,3 \\
Tidak Bekerja & 90 & 45,7 \\
\hline Total & 197 & 100 \\
\hline
\end{tabular}

Dari tabel 1 diatas dapat dilihat distribusi frekuensi pekerjaan terbanyak adalah ibu bekerja sebanyak 107 responden $(54,3 \%)$ dan tidak bekerja sebanyak 90 responden $(45,7 \%)$.

Tabel 2

Distribusi Frekuensi Jadwal Kerja Ibu Di Wilayah Kerja Puskesmas Yosodadi Kota Metro Tahun 2021

\begin{tabular}{ccc}
\hline Jadwal Kerja & Frekuensi & Persentase (\%) \\
\hline Tidak Standar & 88 & 44,7 \\
Standar & 109 & 55,3 \\
\hline Total & 197 & 100 \\
\hline
\end{tabular}

Dari tabel 2 diatas dapat dilihat distribusi frekuensi jadwal kerja dengan persentase terbanyak adalah jadwal kerja standar yaitu 8 jam per hari sebanyak 109 responden $(55,3 \%)$ dan yang tidak standar yaitu $>8$ jam per hari sebanyak 88 responden $(44,7 \%)$. 
Tabel 3

Distribusi Frekuensi Indeks Massa Tubuh Balita Di Wilayah Kerja Puskesmas Yosodadi Kota Metro Tahun 2021

\begin{tabular}{ccc}
\hline IMT & Frekuensi & Persentase (\%) \\
\hline IMT Ideal & 94 & 47,7 \\
IMT Tidak Ideal & 103 & 52,3 \\
\hline Total & 197 & 100 \\
\hline
\end{tabular}

Dari tabel 2 diatas dapat dilihat distribusi frekuensi Dari tabel 3 diatas dapat dilihat distribusi frekuensi IMT dengan persentase terbanyak adalah IMT tidak ideal yaitu $<18,5$ dan $>22,9$ sebanyak 103 responden $(52,3 \%)$ dan IMT ideal yaitu 18,5-22,9 sebanyak 94 responden $(47,7 \%)$.

Analisa Bivariat

Tabel 4

Hubungan Pekerjaan Ibu Dengan Indeks Massa Tubuh Balita Usia 3-5 Tahun Di Wilayah Kerja Puskesmas Yosodadi Kota Metro Tahun 2021

\begin{tabular}{|c|c|c|c|c|c|c|c|c|}
\hline \multirow[t]{3}{*}{ Pekerjaan } & \multicolumn{4}{|c|}{ IMT } & \multirow{2}{*}{\multicolumn{2}{|c|}{ Total }} & \multirow[t]{2}{*}{ OR } & \multirow{3}{*}{$\begin{array}{l}\text { P- } \\
\text { Value }\end{array}$} \\
\hline & \multicolumn{2}{|c|}{ Tidak Ideal } & \multicolumn{2}{|c|}{ Ideal } & & & & \\
\hline & $\mathbf{N}$ & $\%$ & $\mathbf{N}$ & $\%$ & $\mathbf{N}$ & $\%$ & & \\
\hline Bekerja & 73 & 37,1 & 34 & 17,3 & 107 & 54,3 & 7,055 & 0,000 \\
\hline Tidak Bekerja & 21 & 10,7 & 69 & 35,0 & 90 & 45,7 & $(3,736-$ & \\
\hline Total & 94 & 47,7 & 103 & 52,3 & 197 & 100 & $13,323)$ & \\
\hline
\end{tabular}

Pada tabel 4 dapat dilihat responden dengan bekerja sebanyak 107 responden $(54,3 \%)$ dengan IMT tidak ideal 73 responden $(37,1 \%)$ dan IMT ideal sebanyak 34 responden $(17,3 \%)$. Responden dengan status tidak bekerja 90 responden $(45,7 \%)$ dengan IMT tidak ideal 21 responden $(10,7 \%)$ dan IMT ideal 69 responden $(35,0 \%)$.
Hasil uji statistik menggunakan uji chi square didapat nilai $p$-value $=0.000(<\mathrm{a} 0.05)$ yang artinya ada hubungan pekerjaan ibu dengan indeks massa tubuh balita usia 3-5 tahun di Wilayah Kerja Puskesmas Yosodadi Kota Metro Tahun 2021, dengan OR=7,055 yang artinya ibu yang bekerja 7 kali beresiko memiliki anak dengan IMT tidak ideal.

Tabel 5

Hubungan Jadwal Kerja Ibu Dengan Indeks Massa Tubuh Balita Usia 3-5 Tahun Di Wilayah Kerja Puskesmas Yosodadi Kota Metro Tahun 2021

\begin{tabular}{|c|c|c|c|c|c|c|c|c|}
\hline \multirow{3}{*}{$\begin{array}{l}\text { Jadwal } \\
\text { Bekerja }\end{array}$} & \multicolumn{4}{|c|}{ IMT } & \multirow{2}{*}{\multicolumn{2}{|c|}{ Total }} & \multirow[t]{2}{*}{ OR } & \multirow{2}{*}{$\begin{array}{l}\text { P- } \\
\text { Value }\end{array}$} \\
\hline & \multicolumn{2}{|c|}{ Tidak Ideal } & \multicolumn{2}{|c|}{ Ideal } & & & & \\
\hline & $N$ & $\%$ & $\mathbf{N}$ & $\%$ & $\mathrm{~N}$ & $\%$ & & \\
\hline Tidak Standar & 48 & 24,4 & 40 & 20,3 & 88 & 44,7 & 1,643 & 0,085 \\
\hline Standar & 46 & 23,4 & 63 & 32,0 & 109 & 55,3 & $(0,933-$ & \\
\hline Total & 94 & 44,7 & 103 & 52,3 & 197 & 100 & $2,895)$ & \\
\hline
\end{tabular}

Pada tabel 4.5 dapat dilihat responden dengan status jadwal bekerja tidak standar sebanyak 88 responden $(44,7 \%)$ dengan IMT tidak ideal 48 responden $(24,4 \%)$ dan IMT ideal sebanyak 40 responden $(20,3 \%)$. Responden dengan status jadwal bekerja standar 109 
responden $(55,3 \%)$ dengan IMT tidak ideal 46 responden $(44,7 \%)$ dan IMT ideal 63 responden $(32,0 \%)$

Hasil uji statistik menggunakan uji chi square didapat nilai $p$-value $=$ 0.085 (>a0.05) yang artinya tidak ada hubungan jadwal kerja ibu dengan indeks massa tubuh balita usia 3-5 tahun di Wilayah Kerja Puskesmas Yosodadi Kota Metro Tahun 2021, dengan $\mathrm{OR}=1,643$ yang artinya ibu yang memiliki pekerjaan dengan jadwal kerja lebih dari 8 jam tidak berhubungan dengan IMT pada anak

\section{PEMBAHASAN}

\section{Analisa Univariat}

Distribusi Frekuensi Pekerjaan Ibu Di Wilayah Kerja Puskesmas Yosodadi Kota Metro Tahun 2021

Distribusi frekuensi pekerjaan terbanyak adalah ibu bekerja sebanyak 107 responden $(54,3 \%)$ dan tidak bekerja sebanyak 90 responden $(45,7 \%)$.

Sejalan dengan penelitian yang dilakukan oleh Morrisey (2011) Pekerjaan Ibu, Jadwal Kerja, dan Indeks Massa Tubuh Anak. Menggunakan data dari anak usia sekolah di NICHD's Study of Early Child Care and Youth Development ( $\mathrm{N}=990$ ), kami menemukan bahwa peningkatan waktu total seorang ibu bekerja dikaitkan dengan peningkatan BMI anaknya; Selain itu, kami menemukan bahwa hubungan antara pekerjaan ibu dan berat badan anak jauh lebih kuat pada 6 th kelas relatif terhadap usia yang lebih muda.

Sejalan dengan teori yang dikemukakan oleh Ismawati, C. (2009; Nisak, 2018). Profesi wanita bekerja di luar rumah untuk mencari tambahan nafkah, baik untuk dirinya sendiri maupun untuk keluarganya itu berbeda-beda. Beberapa jenis pekerjaan memiliki karakteristik tertentu yang mengarah kepada gender atau jenis kelamin tertentu. Beberapa situasi kerja mengarahkan kepada jenis pekerjaan yang banyak membutuhkan tenaga kerja wanita. Sektor pekerjaan yang banyak membutuhkan tenaga kerja wanita yaitu pada sektor industri dan pada sektor jasa.

Menurut peneliti ibu yang bekerja adalah ibu yang memiliki pekerjaan dengan status pekerjaan baik pada sektor formal ataupun informal dan memiliki reward berupa gaji, berbeda dengan ibu yang tidak bekerja adalah ibu rumah tangga, yang tidak memiliki aktifitas terkait pekerjaan dalam sektor formal ataupun informal.

Pekerjaan orang tua berkaitan dengan pendapatan keluarga, dengan pendapatan yang memadai akan menunjang tumbuh kembang anak karena tercukupinya kebutuhan anak seperti makanan sehat.

Distribusi Frekuensi Jadwal Kerja Ibu Di Wilayah Kerja Puskesmas Yosodadi Kota Metro Tahun 2021

Distribusi frekuensi jadwal kerja dengan persentase terbanyak adalah jadwal kerja standar yaitu 8 jam per hari sebanyak 109 responden $(55,3 \%)$ dan yang tidak standar yaitu $>8$ jam per hari sebanyak 88 responden $(44,7 \%)$

Sejalan dengan penelitian yang dilakukan oleh Fitzsimons (2018) Dampak pekerjaan ibu pada berat badan anak: Bukti dari Inggris. Kami menyelidiki jalur potensial, termasuk perilaku menetap anakanak dan nutrisi, dan menemukan bukti perilaku menetap dan gizi buruk di antara anak-anak yang ibunya bekerja. Ini sesuai dengan tingkat BMI yang lebih tinggi di antara anak-anak ini.

Sejalan dengan teori yang dikemukakan oleh Nafi'ah. (2015; Fauzia, 2019). Pekerjaan orang tua berkaitan dengan pendapatan 
keluarga, sehingga bisa dikatakan bahwa jenis pekerjaan juga bisa menentukan seseorang untuk memenuhi kebutuhan gizi keluarga.

Menurut peneliti jadwal kerja ibu adalah rentang waktu dalam bekerja ibu per hari, baik pekerja sektor formal ataupun informal. Jadwal yang ideal adalah 8 jam per hari, dan akan menjadi tidak ideal apabila ibu bekerja selama lebih dari 8 jam. Sehingga sangat diperlukannya manajemen waktu pada ibu yang bekerja.

Manajemen waktu bukan tentang melakukan banyak hal dalam satu hari. Ini adalah tentang melakukan hal-hal yang paling penting. Manajemen waktu adalah kemampuan untuk memutuskan apa yang paling penting dalam kehidupan baik di tempat kerja, di rumah dan bahkan dalam kehidupan pribadi. Maka dari itu waktu yang sangat berharga dan penting ini harus diatur dan dapat digunakan secara seimbang untuk bekerja, istirahat/tidur, dan waktu luang.

\section{Distribusi Frekuensi Indeks Massa Tubuh Balita Di Wilayah Kerja Puskesmas Yosodadi Kota Metro Tahun 2021}

Distribusi frekuensi IMT dengan persentase terbanyak adalah IMT tidak ideal yaitu < 18,5 dan > 22,9 sebanyak 103 responden $(52,3 \%)$ dan IMT ideal yaitu 18,5-22,9 sebanyak 94 responden $(47,7 \%)$.

Sejalan dengan penelitian yang dilakukan oleh Morrisey (2011) Pekerjaan Ibu, Jadwal Kerja, dan Indeks Massa Tubuh Anak. Menggunakan data dari anak usia sekolah di NICHD's Study of Early Child Care and Youth Development $(\mathrm{N}=990)$, kami menemukan bahwa peningkatan waktu total seorang ibu bekerja dikaitkan dengan peningkatan BMI anaknya; Selain itu, kami menemukan bahwa hubungan antara pekerjaan ibu dan berat badan anak jauh lebih kuat pada 6 th kelas relatif terhadap usia yang lebih muda.

Sejalan dengan teori yang dikemukakan oleh Dhara \& Chatterjee, (2015) Indeks massa tubuh (IMT) merupakan nilai yang diambil dari perhitungan hasil bagi antara berat badan (BB) dalam kilogram dengan kuadrat dari tinggi badan (TB) dalam meter.

Menurut peneliti IMT menunjukkan status gizi dari bentuk keproporsionalan tubuh yang diukur dari berat badan dan tinggi badan yang disesuaikan umur dan jenis kelamin anak. Salah satu upaya menjaga status gizi anak pra sekolah tetap normal adalah dengan memonitor status gizinya setiap bulan. Status gizi dapat diukur dari Indek Massa Tubuh (IMT) yang didasarkan pada umur anak tersebut.

Kelebihan gizi anak pra sekolah akan memberikan dampak bagi kesehatan anak pada umur selanjutnya bahkan sampai dewasa kelak. Dampak buruk obesitas pada anak-anak diantaranya adalah obesitas dapat berlanjut hingga dewasa, pertumbuhan anak terganggu, dapat menyebabkan gangguan psikologis, daya tahan tubuh menurun, perubahan sendi, gangguan pernafasan, prestasi akademis terganggu, hingga berbagai penyakit tidak menular seperti penyakit jantung dan pembuluh darah, dan diabetes (Kemenkes RI, 2018).

\section{Analisa Bivariat}

Hubungan Pekerjaan Ibu Dengan Indeks Massa Tubuh Balita Usia 3-5 Tahun Di Wilayah Kerja Puskesmas Yosodadi Kota Metro Tahun 2021

Hasil uji statistik menggunakan uji chi square didapat nilai $p$-value = 0.000 (<a0.05) yang artinya ada hubungan pekerjaan ibu dengan 
indeks massa tubuh balita usia 3-5 tahun di Wilayah Kerja Puskesmas Yosodadi Kota Metro Tahun 2021.

Sejalan Dengan Penelitian Yang Dilakukan Oleh Maisarah (2018) Hubungan Status Pekerjaan Ibu, Tingkat Pendapatan Keluarga, Tingkat Pengetahuan Ibu Tentang Gizi Dan Pemberian Asi Eksklusif Terhadap Status Gizi Balita. Hasil penelitian menunjukkan terdapat hubungan yang signifikan antara tingkat pengetahuan ibu tentang gizi dan pemberian ASI eksklusif dengan status gizi balita (pengetahuan gizi $p=0,001$ OR $=20,928 \mathrm{Cl}=95 \% 3,44$ 127,17 ; pemberian ASI eksklusif $\mathrm{p}=0,003$ OR $=6,64 \mathrm{Cl} 95 \%=1,91$ 23,12).

Sejalan dengan teori yang dikemukakan oleh Hidayat (2012) Pengukuran berat badan digunakan untuk menilai hasil peningkatan atau penurunan semua jaringan yang ada pada tubuh, misalnya tulang, otot, organ tubuh, dan cairan tubuh sehingga dapat diketahui status gizi dan tumbuh kembang anak, berat badan juga dapat digunakan sebagai dasar perhitungan dosis dan makanan yang diperlukan dalam tindakan pengobatan

Hasil penelitian ini didapat responden dengan bekerja sebanyak 107 responden (54,3\%) dengan IMT tidak ideal 73 responden $(37,1 \%)$ dan IMT ideal sebanyak 34 responden $(17,3 \%)$. Menurut peneliti Indeks massa tubuh merupakan alat sederhana untuk memantau status gizi orang dewasa khususnya yang berkaitan dengan kelebihan dan kekurangan berat badan. ibu yang bekerja dengan lokasi pekerjaan yang jauh dari rumah atau tempat tinggal, karena anak tidak akan mendapat perhatian yang lebih terutama dalam hal pemberian makan dan perawatan anak. Anak akan mudah mengalami penyakit malnutrisi jika ibu meninggalkan anak karena memiliki pekerjaan tetap diluar rumah.

Responden dengan status tidak bekerja 90 responden $(45,7 \%)$ dengan IMT tidak ideal 21 responden $(10,7 \%)$ dan IMT ideal 69 responden $(35,0 \%)$. Meningkatnya pendapatan dalam keluarga berarti dapat meningkatkan juga peluang untuk membeli pangan atau makanan dengan mutu yang baik dan jumlah yang sesuai, sebaliknya pendapatan yang menurun atau rendah akan menyebabkan menurunnya juga daya beli keluarga untuk pemenuhan bahan pangan yang berkualitas dengan jumlah yang sesuai yang nantinya dapat meningkatkan status gizi serta asupan gizi yang baik pula. Menurut peneliti Status gizi merupakan suatu keadaan yang diakibatkan oleh keseimbangan antara asupan zat gizi yang berasal dari makanan dan kebutuhan zat gizi oleh tubuh. Masalah gizi dapat diartikan sebagai kesenjangan yang terjadi akibat keadaan gizi yang diharapkan tidak sesuai dengan keadaan gizi yang ada karena gangguan pemanfaatan gizi.

Menurut peneliti pekerjaan dan penghasilan orang tua yang tinggi bukanlah jaminan akan memiliki status gizi yang baik, karena masih ada beberapa faktor yang saling berkaitan seperti tingkat pendidikan dan pengetahuan orang tua tentang gizi yang baik, banyaknya jumlah anggota keluarga yang akan dinafkahi, jarak kelahiran yang terlalu dekat juga sangat mempengaruhi dalam pemberian asi, dan pola pengasuhan

Hubungan Jadwal Kerja Ibu Dengan Indeks Massa Tubuh Balita Usia 3-5 Tahun Di Wilayah Kerja Puskesmas Yosodadi Kota Metro Tahun 2021

Hasil uji statistik menggunakan uji chi square didapat nilai $p$-value $=$ 0.085 (>a0.05) yang artinya tidak 
ada hubungan jadwal kerja ibu dengan indeks massa tubuh balita usia 3-5 tahun di Wilayah Kerja Puskesmas Yosodadi Kota Metro Tahun 2021.

Hasil penelitian ini tidak sejalan dengan penelitian yang dilakukan oleh Siregar (2019) Keterlibatan Ibu Bekerja Dalam Perkembangan Pendidikan Anak. Keterlibatan ibu yang bekerja tidak membuat perkembangan pendidikan anak terbengkalai.

Sejalan dengan pendapat yang dikemukakan oleh Adriani dan Wirjatmadi. (2014; Rorong, 2019) Status sosial ekonomi dalam hal ini juga berperan penting dalam pemenuhan gizi dan masalah gizi. Keluarga dengan jumlah anak yang banyak dan jarak kelahiran yang sangat dekat akan menimbulkan lebih banyak masalah, yakni pendapatan keluarga pas-pasan sedangkan anak banyak maka pemerataan dan kecukupan di dalam keluarga akan sulit dipenuhi.

Hasil penelitian ini didapat responden dengan status jadwal bekerja tidak standar sebanyak 88 responden $(44,7 \%)$ dengan IMT tidak ideal 48 responden $(24,4 \%)$ dan IMT ideal sebanyak 40 responden (20,3\%). Meningkatnya pendapatan dalam keluarga berarti dapat meningkatkan juga peluang untuk membeli pangan atau makanan dengan mutu yang baik dan jumlah yang sesuai, sebaliknya pendapatan yang menurun atau rendah akan menyebabkan menurunnya juga daya beli keluarga untuk pemenuhan bahan pangan yang berkualitas dengan jumlah yang sesuai yang nantinya dapat meningkatkan status gizi serta asupan gizi yang baik pula (Sulistyoningsih, 2011).

Responden dengan status jadwal bekerja standar 109 responden (55,3\%) dengan IMT tidak ideal 46 responden $(44,7 \%)$ dan IMT ideal 63 responden $(32,0 \%)$. Status gizi anak sangat dipengaruhi oleh keluaga yang memiliki pendapatan yang rendah. Pendapatan keluarga yang rendah dapat berakibat langsung pada penyediaan makanan dalam keluarga, dimana keluarga akan mengalami masalah dalam ketersediaan makanan sesuai dengan kebutuhan, sehingga dapat berdampak dan terganggunya status gizi anak.

Menurut peneliti ketiadaan hubungan jadwal pekerjaan dengan status gizi anak prasekolah baik secara IMT/U maupun TB/U dapat disebabkan karena beberapa hal yang menjadi keterbatasan dalam penelitian ini. Keterbatasan penelitian ini adalah jumlah sampel yang sedikit, dan munculnya faktor bias yang mempengaruhi status gizi balita yang tidak diukur yaitu tingkat pengetahuan dan pendidikan ibu.

\section{KESIMPULAN}

1. Distribusi frekuensi pekerjaan terbanyak adalah ibu bekerja sebanyak 107 responden (54,3\%).

2. Distribusi frekuensi jadwal kerja dengan persentase terbanyak adalah jadwal kerja standar yaitu 8 jam per hari sebanyak 109 responden $(55,3 \%)$.

3. Distribusi frekuensi IMT dengan persentase terbanyak adalah IMT tidak ideal yaitu < 18,5 dan $>22,9$ sebanyak 103 responden (52,3\%)

4. Hasil uji statistik menggunakan uji chi square didapat nilai $p$ value $=0.000 \quad(<\mathrm{a} 0.05)$ yang artinya ada hubungan pekerjaan ibu dengan indeks massa tubuh balita usia 3-5 tahun di Wilayah Kerja Puskesmas Yosodadi Kota Metro Tahun 2021.

5. Hasil uji statistik menggunakan uji chi square didapat nilai $p$ value $=0.085 \quad(>\mathrm{a} 0.05)$ yang artinya tidak ada hubungan jadwal kerja ibu dengan indeks 
massa tubuh balita usia 3-5 tahun di Wilayah Kerja Puskesmas Yosodadi Kota Metro Tahun 2021.

\section{Saran}

\section{Bagi Puskesmas Yosodadi Kota} Metro

Bagi Puskesmas Yosodadi Kota Metro diharapkan dapat melakukan penyuluhan bagi ibu yamg bekerja diluar rumah baik pekerjaan sektor formal ataupun informal untuk tetap mengikuti psoyandu anak, agar dapat memantau berat badan anak.

\section{Bagi Orangtua/ Ibu}

Disarankan kepada orang tua yang memiliki balita dengan status gizi kurus dan gemuk, harus lebih memperhatikan lagi mengenai pola asuh anak. Dalam hal ini pemberian makanan, yaitu makanan yang mengandung zat-zat gizi seperti kabohidrat (nasi), protein (telur dan ikan), lemak (daging), dan vitamin (sayur dan buah).

\section{DAFTAR PUSTAKA}

Anwar, D. P., \& Fauziah, N. (2019). Hubungan antara kesejahteraan psikologis dengan konflik peran ganda pada wanita yang bekerja sebagai polisi di Polrestabes Semarang. Empati, 8(1), 105110.

Berman, A., Snyder, S. J., Kozier, B., Erb, G. L., Levett-Jones, T., Dwyer, T., ... \& Stanley, D. (2014). Kozier \& Erb's fundamentals of Nursing Australian edition (Vol. 3). Pearson Higher Education AU.

Dhara, S., \& Chatterjee, K. (2015). A study of VO2 max in relation with body mass index (BMI) of physical education students. Research Journal of Physical Education Sciences

ISSN, 2320,

Fitriani, Aritonang, E. Y., \& Ashar, T. (2016). Pengaruh Karakteristik, Aktifitas Fisik dan Penambahan Berat Badan Ibu Hamil Terhadap Kejadian Preeklamsia di RSUD Rantauprapat.

Hidayat, T. S., \& Jahari, A. B. (2012). Perilaku pemanfaatan posyandu hubungannya dengan status gizi dan morbiditas balita. Buletin Penelitian Kesehatan, 40(1), 1-10.

Kurdanti, W., Suryani, I., Syamsiatun, N. H., Siwi, L. P., Adityanti, M. M., Mustikaningsih, D., \& Sholihah, K. I. (2015). Faktorfaktor yang mempengaruhi kejadian obesitas pada remaja. Jurnal Gizi Klinik Indonesia, 11(4), 179-190.

Marmi. (2011). Asuhan Kebidanan Pada Ibu Hamil. Yogyakarta: Penerbit Pelajar.

Muharry, A., Kumalasari, I., \& Dewi, E. R. (2017). Faktor yang Mempengaruhi Status Gizi Balita di Puskesmas Nelayan Kota Cirebon. JI-KES (Jurnal Ilmu Kesehatan), 1(1).

Nisak, N. Z., Titik Susilowati, S. K. M., \& Gizi, M. (2018). Hubungan Pekerjaan dan Pengetahuan Gizi Ibu dengan Status Gizi Balita Desa Duwet Kecamatan Wonosari Kabupaten Klaten (Doctoral dissertation, Universitas Muhammadiyah Surakarta).

Novikasari, L., Zainaro, M. A., Wardiyah, A., \& Trismiyana, E. (2019). Penyuluhan Kesehatan Tentang Pentingnya Imunisasi Mr (Measles Rubela) Di Puskesmas Simpur Bandar Lampung. Jurnal Kreativitas 
Pengabdian Kepada

Masyarakat (PKM), 2(2), 133138.

Notoatmodjo, S. (2018). Metodologi Riset Keperawatan. Jakarta: Rinekacipta.

Prawirohardjo, S. (2016). FaktorFaktor Yang Mempengaruhi Program $\mathrm{Kb} \quad \mathrm{Ilmu}$ Kebidanan. Jakarta: Bina Pustaka.

Profil Kemenkes Ri (2018). Angka Kematian Ibu Dan Bayi.

Profil Kemenkes Ri. (2019). Angka Kejadian Kek.

Rorong, A. P. (2019). Hubungan Antara Status Sosial Ekonomi Keluarga Dengan Status Gizi Anak Sekolah Dasar Kelurahan Bailang Kecamatan Bunaken Kota Manado. KESMAS, 8(2).

Supariasa. (2012). Penilaian Status Gizi. Jakarta: EGC.

Wardiyah, A., Rilyani. (2016). Sistem Reproduksi (Lengkap Dengan Latihan Uji Kompetensi Perawat). Jakarta: Salemba Medika.
Zainaro, M. A., Gunawan, M. R., \& Suhartini, S. (2020). FaktorFaktor Yang Berhubungan Dengan Produktivitas Kerja Tenaga Kesehatan Di Puskesmas Tulang Bawang I Kabupaten Tulang Bawang. Malahayati Nursing Journal, 2(4), 747-757.

Zainaro, M. A., Kusumaningsih, D., \& Karyanto, K. (2019). Hubungan Pelayanan Dan Fasilitas Kesehatan Dengan Kepuasan Pasien Pada Pelayanan Manajemen Terpadu Balita Sakit (MTBS) Di Puskesmas Karya Tani Kabupaten Lampung Timur. Malahayati Nursing Journal, 1(1). 